\title{
Biogen in European Patent Office row over interferon
}

\section{Washington}

BIOGEN, the international biotechnology firm, is once again under fire. In a recent oral decision, the European Patent Office (EPO) revoked Biogen's patent for recombinant alpha-interferon, saying the patent was too broad. As the first major biotechnology patent to be disputed with EPO, the Biogen alpha-interferon case may serve as a bellwether for the industry.

EPO's scrutiny of Biogen came as a result of pressure brought to bear by several pharmaceutical companies involved in interferon research. The patent gave Biogen sole proprietary rights over all methods used to produce any form of alphainterferon by recombinant means. The EPO examiners ruled that recombinant alpha-interferon is a patentable invention, but would not support a patent that covered more than Biogen's culture deposit at EPO. Because Biogen had only described the cloning and expression of one gene for alpha-interferon in one possible vector, the examiners objected to the scope of Biogen's claims. Biogen intends to appeal against the decision, which could take 2 to 3 years to resolve.

According to Robert Gottlieb of Biogen, a patent covering only Biogen's deposit would be so narrow as to have "no commercial value". Other companies could make slight changes in amino-acid sequence or use another vector without infringing the patent.

Biogen won the patent for alphainterferon in 1984. It then entered into a licensing agreement with ScheringPlough to market the product under the trade name Intron A. Under the agreement, Schering-Plough assumed the onus for seeking regulatory approval for the product. The role of alpha-interferon in preventing viral infections has made it a likely candidate as a therapeutic or prophylactic for a myriad of diseases, including cancer. So far, Intron A has received Food and Drug Administration (FDA) approval for the treatment of hairy-cell leukaemia. Applications are pending with FDA for using Intron $A$ to treat genital warts, malignant melanoma, multiple myeloma and Kaposi's sarcoma, a cancer related to AIDS (acquired immune deficiency syndrome).

The revocation of Biogen's European patent for alpha-interferon will not affect Schering-Plough's sales of Intron A, reported to total \$8-10 million per year. Biogen receives 10 per cent of that amount. Nor is the patent immediately up for grabs; patents under appeal are still protected under European patent law. Competing companies must wait for a final decision before they can exploit the technology for profit without threat of an infringement suit. But future sales could drop if the patent is not upheld under the appeal. Companies now on the sidelines could well become competing players in the alpha-interferon market.

Lately, Biogen has been struggling (see Nature 324, 402; 1986) to overcome a legacy of poor management and come back into its own as one of the initially most successful biotech start-ups. But Biogen lost 20.5 million in the first nine months of
1986, and its reserves will not last long. A new stock offering pumped $\$ 40$ million into Biogen's coffers, and active licensing may help, because the company is rich in product diversity. A new licensing agreement with Baxter Travenol for gammainterferon, now in the final stage of clinical trials, increases Biogen's licensing agreements to nearly thirty. EPO's decision to revoke Biogen's patent may indicate that European biotechnology patents will be more stringent than those in the United States. But the decision may merely reflect the conservatism that has surrounded biotechnology. In time, standards of patentability may not be all that different.

\section{Afghanistan Academy of Sciences finally gets under way}

\section{London}

AfGHANistan's Academy of Sciences, founded in 1979, after the Sowr (proSoviet) revolution, and shortly before Soviet military intervention, is to be transformed into a "centre for organizing scientific research and scientific thinking", according to a decision last month of the Afghan Council of Ministers and the politburo of the People's Democratic Party of Afghanistan. This follows an "assess-

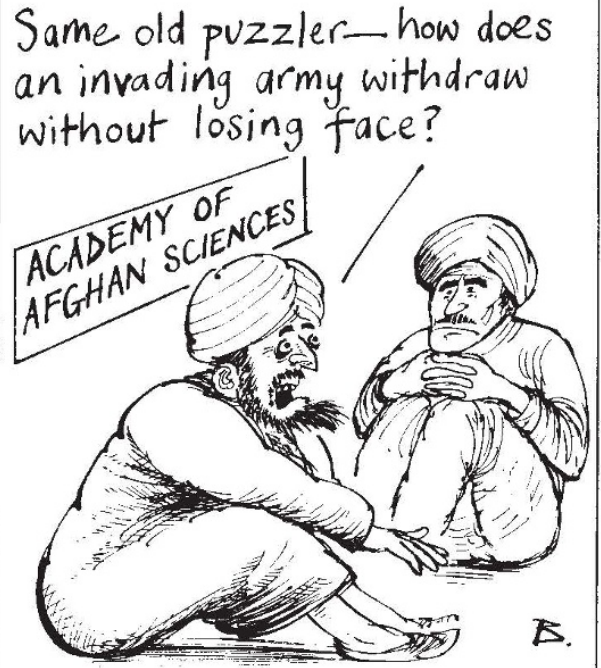

ment" of the work of the academy by the politburo and Council of Ministers, which, according to the official announcements, "manifests the attention given by the party and revolutionary state to the growth of science and technology and the enhancement of their role in the country's economic, social and cultural life".

Although the academy, at least according to the reference books, has for some time possessed a number of institutes for the natural and social sciences and the humanities, it has not, until now, had a formal complement of academicians and candidate academicians. This defect has now been remedied; on the recommenda- tion of various ministries and 'establishments', a general assembly of the academy has been set up, consisting of 9 academicians and 32 candidate members, who will receive additional monthly salaries of 10,000 afghanis for academicians and 5,000 afghanis for candidates, which even under the present conditions of warinduced inflation will mean a virtual doubling of salaries for the academicians and a useful boost for the candidates.

Interestingly, the official announcements make no mention of the post of president of the academy. The first president, the Moscow-educated Dr Mojawer Ahmad Lyar, was eased out of office in the early 1980 s by being sent on a protracted study trip to East Germany. In 1986, international directories name the president of the academy as $\mathrm{Dr}$ Gul Mohammed Noorzai, a name which, remarkably, is absent from the new list of the general assembly of the academy.

European experts on Afghanistan have pointed out that several full academicians have political backgrounds, including the poet Soleyman La'eq and Faqir Mohammad Yaqubi, a minister without portfolio. This is perhaps not surprising, as the decision establishing the general assembly stress its role in "implementing the revolutionary transformations in the country" as well as "enhancing the role of science in economic and social life". More noteworthy, say the experts, is that, except for these political figures and a few exceptions such as Professor Abol Ahmad Dawid, former rector of Kabul University, the members of the general assembly of the Afghan Academy of Sciences are almost unknown. But most of Afghanistan's former echelons of scholars, the experts say, are either abroad, dead, disappeared, or in prison, in the case of $\mathrm{Dr}$ Mohammad Younis Akhbari, under sentence of death (see Nature 323, 747; 1986). 